\title{
UJI AKTIVITAS PERTUMBUHAN RAMBUT KELINCI JANTAN DARI SEDIAAN HAIR TONIC YANG MENGANDUNG EKSTRAK ETANOL DAUN MANGKOKAN (Nothopanax scutellarium L.)
}

\author{
Hair Growth Activity Test of Male Rabbit with Hair Tonic Preparation which Contains \\ Ethanol Extract of Nothopanax scutellarium L.
}

\section{Qurrota Aini}

Dinas Kesehatan Provinsi Lampung

\begin{abstract}
Preparation stimulating hair growth (hair tonic) is cosmetic preparations used for volumizing hair growth or stimulate hair growth on balding or hair loss. This research aims to formulate hair tonic preparation of extract Nothopanax scutellarium and determine the effect of dosage formulation hair tonic $N$. scutellarium towards the growth of male rabbit. This research makes five sample formula with active ingredients extract $N$. scutellarium with concentration $0 \%$ (basic hair tonic), 25\%,35\%, 45\% and positive control (hair tonic preparations containing minoxidil). The treatment is done every day with the volume every time the basting of one mili liter each plot every day for twenty one days. Hair Length measurements performed on days $8^{\text {th }}, 15^{\text {th }}$ and $22^{\text {nd }}$ using calipers and the hair weight measurements performed on day 22 by way of shaved hair grows and then weighed. Data were analyzed using ANOVA test. The data length and weight of the negative control hair, formula- $A$ (25\%), formula- $B$ (35\%), formula-C (45\%) and positive control at day 22 in a row is 11.56, 16.19, 14.60, 14.10, $18.58 \mathrm{~mm}$ and 387.325, 390.85, 386.9, 387.275, $392.1 \mathrm{mg}$. Dosage formulations hair tonic of $N$. scutellarium extract can increase hair growth male rabbits.
\end{abstract}

Keywords : hair grower, extract of Nothopanax scutellarium, anova.

\begin{abstract}
Abstrak
Sediaan perangsang pertumbuhan rambut (hair tonic) adalah sediaan kosmetik yang digunakan untuk merangsang pertumbuhan rambut pada kebotakan atau rambut rontok. Penelitian ini bertujuan membuat formulasi sediaan hair tonic dari ekstrak etanol daun mangkokan dan mengetahui efek formulasi sediaan hair tonic ekstrak etanol daun mangkokan terhadap pertumbuhan rambut kelinci jantan ditinjau dari panjang dan bobot rambut. Penelitian ini membuat 5 formula sampel dengan bahan aktif ekstrak etanol daun mangkokan dengan konsentrasi 0\% (Kontrol negatif), 25\%, $35 \%, 45 \%$ dan kontrol positif (sediaan hair tonic yang mengandung minoxidil). Perlakuan dilakukan setiap hari dengan volume pengolesan $1 \mathrm{ml}$ setiap konsentrasi selama 21 hari. Pengukuran panjang rambut dilakukan pada hari ke 8,15 dan 22 menggunakan jangka sorong dan pengukuran bobot rambut dilakukan pada hari ke 22 dengan cara mencukur rambut yang tumbuh kemudian ditimbang. Data dianalisis menggunakan uji ANOVA. Data panjang dan bobot rambut kontrol negatif, formula $A$ $(25 \%)$, formula B $(35 \%)$, formula C $(45 \%)$ dan kontrol positif pada hari ke- 22 berturutturut adalah 11.56, 16.19, 14.60, 14.10, $18.58 \mathrm{~mm}$ dan 387.325, 390.85, 386.9, $387.275,392.1 \mathrm{mg}$. Hasil uji ANOVA menjelaskan bahwa formulasi sediaan hair tonic ekstrak etanol daun mangkokan memiliki efek dapat meningkatkan pertumbuhan rambut kelinci jantan.
\end{abstract}

Kata kunci : Penumbuh rambut, ekstrak etanol daun mangkokan, anova. 


\section{PENDAHULUAN}

Rambut mempunyai peranan yang sangat penting bagi manusia. Rambut berperan sebagai proteksi terhadap lingkungan yang merugikan, antara lain suhu dingin atau panas dan sinar ultraviolet. Selain itu, rambut juga berfungsi sebagai pengatur suhu, pendorong penguapan keringat dan sebagai indera peraba yang sensitif. Di era sekarang ini, peranan rambut lebih condong pada keserasian dan estetika. Kerontokan rambut dapat disebabkan oleh beberapa faktor, antara lain umur, genetik, ras tertentu, hormonal, imunologis, defisiensi gizi, stres psikis, trauma fisik, penyakit kulit tertentu, penyakit sistemik, obat sistemik dan penyebab lain yang belum diketahui.

Salah satu cara pencegahan kerontokan rambut dapat dilakukan dengan melakukan perawatan rambut. Perawatan rambut memerlukan berbagai kosmetik, mulai dari kosmetik pembersih rambut, hair kondisioner, kreambat, sampai hair tonic [1]. Cara yang mudah dilakukan untuk merawat rambut rontok adalah dengan melakukan perawatan rambut menggunakan hair tonic sebagai bahan untuk menutrisi rambut.

Perangsang pertumbuhan rambut (hair tonic) adalah sediaan yang mengandung bahan-bahan yang diperlukan oleh rambut, akar rambut dan kulit kepala [1]. Saat ini, sediaan hair tonic sudah terdapat banyak di pasaran baik dari bahan kimia maupun dari bahan herbal. Penggunaan bahan-bahan kimia pada produk kosmetika dinilai kurang aman karena dapat menimbulkan efek samping pada penggunaan jangka panjang. Salah satu bahan kimia sintetis yang biasa digunakan dalam hair tonic sebagai zat berkhasiat adalah minoksidil yang memiliki efek samping alergi pada kulit, sakit kepala, vertigo, lemas dan edema [2].

Penggunaan bahan herbal telah diterima secara luas di negara berkembang dan negara maju pada bidang pengobatan maupun pada bidang kosmetik. Kekayaan alam Indonesia yang melimpah, terutama dari segi keanekaragaman floranya mendukung penggunaan bahan herbal. Sejak dahulu, nenek moyang kita sudah mengenal cara perawatan rambut menggunakan tumbuhan.

Mangkokan (Nothopanax scutellarium L.) merupakan tanaman yang banyak tumbuh di Indonesia, biasanya tanaman ini tumbuh di pekarangan rumah masyarakat. Tanaman mangkokan tidak hanya digunakan sebagai tanaman hias, tetapi juga diduga berkhasiat untuk mengatasi luka, sukar kencing, radang payudara dan membantu pertumbuhan rambut [3].

Manfaat daun mangkokan sebagai penumbuh rambut sudah dibuktikan bahwa pada konsentrasi $25 \%$ ekstrak daun mangkokan sudah memiliki aktivitas pertumbuhan rambut [4]. Selain itu, hasil penelitian lain menunjukkan bahwa daun mangkokan mempunyai efek mempercepat pertumbuhan rambut pada kelinci jantan [5].

Sediaan hair tonic dipilih karena bentuknya yang berupa cairan sehingga mudah diaplikasikan dan tidak lengket seperti sediaan semi padat sehingga tidak meninggalkan kerak yang dapat memicu terbentuknya ketombe.

Penelitian ini bertujuan memformuasikan daun mangkokan menjadi hair tonic sehingga penggunaanya lebih mudah dan efisien. Adanya zat tambahan dalam hair tonic dapat membuat penetrasi 
sediaan di kulit kepala lebih baik dari pada ekstraknya sehingga zat berkhasiat pada daun mangkokan lebih terserap sempurna pada kulit kepala. Selain itu, penelitian ini juga bertujuan melihat kestabilan fisik dari formulasi sediaan hair tonic yang dibuat.

\section{METODE PENELITIAN}

\section{Alat dan Bahan}

Alat-alat yang digunakan, antara lain evaporator, timbangan analitik, lemari pendingin (LG), viskometer ostwald, pinset, oven (Memmert, Jerman), $\mathrm{pH}$ meter, jangka sorong, kain flanel, batang pengaduk, piknometer, alat cukur, pinset dan alat-alat gelas.

Bahan-bahan yang digunakan, antara lain 4 ekor kelinci, daun mangkokan, 95\% etanol, aquadest, propilen glikol, pewarna hijau, parfum jasmine, metil paraben dan kontrol positif REGROU.

\section{Prosedur Penelitian}

\section{Pengambilan Bahan Uji}

Daun mangkokan ( $N$. scutellarium L.) berwarna hijau tua dan berukuran yang sama diambil dari tanaman mangkokan yang tumbuh di Jl. Mayjen Sutyoso, Kotabaru Tanjung Karang Timur, Bandar Lampung.

\section{Determinasi bahan uji}

Determinasi dilakukan di Laboratorium Botani Jurusan Farmasi Fakultas MIPA Universitas Tulang Bawang (UTB) Lampung. Determinasi bertujuan untuk meyakinkan bahwa spesies dari daun mangkokan yang digunakan adalah spesies Nothopanax scutellarium L.

\section{Pembuatan ekstrak etanol daun mangkokan}

Daun mangkokan yang akan digunakan dibuat simplisia dengan cara dicuci bersih, kemudian dikeringkan terlebih dahulu dibawah sinar matahari secara tidak langsung (ditutupi kain hitam). Setelah betulbetul kering, kemudian dirajang kasar. Simplisia daun mangkokan ditimbang kemudian dimaserasi dengan 70\% etanol lalu disimpan selama 1 hari. Setelah itu, maserat disaring menggunakan kain flanel. Maserat yang diperoleh lalu disimpan (Filtrat A). Simplisia daun mangkokan dimaserasi kembali dengan $70 \%$ etanol selama 1 hari sambil sering diaduk kemudian disaring lagi dengan kain flanel (Filtrat B), seterusnya hingga maserat benar-benar jernih. Selanjutnya filtrat $A$, filtrat $B$ sampai maserat terakhir dicampurkan lalu dipekatkan menggunakan rotary evaporator sampai pelarut menguap sempurna dan ekstrak menjadi kental. Ekstrak yang diperoleh disimpan dalam botol.

\section{Pembuatan Formula Sediaan}

Bahan yang akan dibuat untuk satu sediaan adalah $100 \mathrm{~mL}$, maka perhitungan bahan-bahan yang diperlukan seperti Tabel 1. Pembuatan formula sediaan dibuat dengan cara bahan-bahan semua ditimbang. Ekstrak daun mangkokan dilarutkan dengan akuades sedangkan metil paraben dilarutkan dengan etanol secukupnya dan ditambahkan propilen glikol sedikit demi sedikit. Larutan ekstrak daun mangkokan dicampurkan dengan larutan metil pareban. Larutan tersebut ditambahkan dengan pewarna dan parfum serta akuades hingga $100 \mathrm{ml}$ (Tabel 1).

Komposisi kontrol positif (REGROU) yang digunakan adalah : $2 \%$ 
Minoxidil, 53.4\% etanol, propilen glikol dan air murni ad $30 \mathrm{~mL}$.

\section{Penyiapan Hewan Uji}

Hewan uji yang digunakan adalah 4 ekor kelinci putih jantan yang berumur 3-4 bulan dengan bobot rata-rata 1.8$2.5 \mathrm{~kg}$. Sebelum dilakukan percobaan, kelinci perlu diadaptasikan terlebih dahulu terhadap tempat, kandang, dan makanan selama satu minggu. Hewan yang mengalami penurunan berat badan lebih dari $10 \%$, tidak digunakan dalam percobaan. Selama adaptasi dan pengujian hewan uji diberikan makan dan minum dengan jenis dan jumlah yang sama.

Tabel 1. Komposisi masing-masing formula sediaan

\begin{tabular}{c|c|c|c|c|c}
\hline No & Bahan & $\begin{array}{c}\text { Kontrol } \\
\text { negatif }\end{array}$ & Formula A & Formula B & Formula C \\
\hline 1 & $\begin{array}{c}\text { Ekstrak daun } \\
\text { mangkokan }\end{array}$ & - & $25 \mathrm{~g}$ & $35 \mathrm{~g}$ & $45 \mathrm{~g}$ \\
\hline 2 & Etanol 96\% & $20 \mathrm{ml}$ & $20 \mathrm{ml}$ & $20 \mathrm{ml}$ & $20 \mathrm{ml}$ \\
\hline 3 & Propilen Glikol & $15 \mathrm{ml}$ & $15 \mathrm{ml}$ & $15 \mathrm{ml}$ & $15 \mathrm{ml}$ \\
\hline 4 & Metil Paraben & $0,1 \mathrm{~g}$ & $0,1 \mathrm{~g}$ & $0,1 \mathrm{~g}$ & $0,1 \mathrm{~g}$ \\
\hline 5 & Pewarna Hijau & $\mathrm{qs}$ & $\mathrm{Qs}$ & $\mathrm{qs}$ & $\mathrm{qs}$ \\
\hline 6 & Parfum Jasmine & $\mathrm{qs}$ & $\mathrm{Qs}$ & $\mathrm{qs}$ & $\mathrm{qs}$ \\
\hline 7 & Aquadest & Ad $100 \mathrm{ml}$ & Ad $100 \mathrm{ml}$ & Ad $100 \mathrm{ml}$ & $\mathrm{Ad} 100 \mathrm{ml}$ \\
\hline
\end{tabular}

\section{Uji Pertumbuhan Rambut}

Metode yang digunakan untuk uji pertumbuhan rambut berdasarkan Tanaka, et al (1980). Hewan uji yang digunakan berupa kelinci sebanyak 4 ekor. Perlakuan yang diberikan diantaranya punggung kelinci dicukur mengunakan gunting dan pisau cukur, kemudian di bagi menjadi 6 daerah dengan masing-masing sisi yang lebih kurang $2 \mathrm{~cm}$, dan antara daerah yang satu dengan daerah yang lain diberi jarak lebih kurang $1 \mathrm{~cm}$. Setiap bagian diberi perlakuan sebagai berikut :

1. Daerah I tidak ditetesi apapun sebagai blanko

2. Daerah II ditetesi hair tonic yang tidak mengandung zat berkhasiat (kontrol negatif)

3. Daerah III ditetesi hair tonic dengan konsentrasi ekstrak daun mangkokan 25\% (Formula A)
4. Daerah III ditetesi hair tonic dengan konsentrasi ekstrak daun mangkokan 25\% (Formula A)

5. Daerah III ditetesi hair tonic dengan konsentrasi ekstrak daun mangkokan $25 \%$ (Formula A)

6. Daerah IV ditetesi hair tonic dengan konsentrasi ekstrak daun mangkokan 35\% (Formula B)

7. Daerah $\mathrm{V}$ ditetesi hair tonic dengan konsentrasi ekstrak daun mangkokan $45 \%$ (Formula C)

8. Daerah VI ditetesi hair tonic Regrou (kontrol positif). 

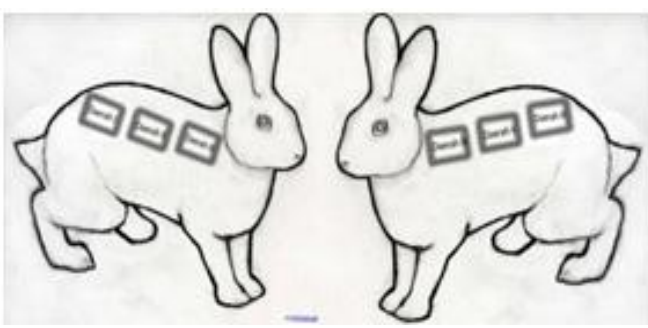

Gambar 1. Bagian rambut kelinci yang diberi perlakuan

Pemberian hair tonic dilakukan 1 kali sehari dengan volume $1 \mathrm{~mL}$ pada masing-masing bagian. Hari pertama penetesan dianggap hari ke-1. Pemberian hair tonic dilakukan selama 21 hari.

Pengamatan panjang rambut tiap daerah dilakukan pada hari ke-8, 15 dan 22. Sebelum diukur, rambut dicabut sebanyak 10 helai yang terpanjang kemudian diletakkan pada kertas hitam. Untuk mempermudahkan pengukuran, rambut kelinci diletakkan pada selotip bening kemudian diukur panjangnya dengan jangka sorong.

Selain mengukur panjang rambut, dilakukan juga pengukuran bobot rambut untuk mengetahui kelebatan rambut. Pengukuran bobot dilakukan pada hari ke 22 dengan cara mencukur semua rambut pada masing-masing daerah uji kemudian timbang rambut pada masing-masing daerah tersebut menggunakan timbangan digital. Hasil yang diperoleh dihitung secara statistik.

\section{Analisis Data}

Untuk mengetahui pengaruh ekstrak etanol daun mangkokan terhadap bobot dan panjang rambut pada kelinci jantan, analisa data pada rancangan penelitian ini menggunakan analisis varian (ANOVA) kemudian dilanjutkan dengan uji beda nyata terkecil (BNT).

\section{HASIL DAN PEMBAHASAN}

\section{Hasil Penelitian}

\section{Uji determinasi}

Hasil pengamatan morfologi dan anatomi tanaman daun mangkokan yang digunakan dalam penelitian ini termasuk spesies Nothopanax scutellarium L.

\section{Pembuatan ekstrak}

Sebanyak $4.2 \mathrm{~kg}$ daun mangkokan segar dijemur dibawah sinar matahari dengan ditutup kain hitam dan diperoleh simplisia kering daun mangkokan sebanyak 645 gram. Selanjutnya dirajang kasar dan dilakukan proses maserasi sebanyak 4 kali pengulangan (4 hari) sehingga diperoleh maserat sebanyak 8.7 liter.

Selanjutnya maserat dipekatkan menggunakan rotary evaporator sehingga diperoleh ekstrak kental sebanyak 242 gram.

\begin{tabular}{l|c|c} 
Formula A & Formula B & Formula C \\
\hline & &
\end{tabular}

Gambar 2. Hasil pembuatan hair tonic dari formula $\mathrm{A}, \mathrm{B}$ dan C

\section{Sifat Fisik Sediaan Hair Tonic}

Pengamatan organoleptis pada formula A (25\% ekstrak mangkokan), formula B (35\% ekstrak mangkokan) dan formula C $(45 \%$ ekstrak mangkokan) semua memiliki warna hijau, aroma jasmine, homogen. 
Pemeriksaan $\mathrm{pH}$ diperoleh $\mathrm{pH}$ formula A, formula $B$ dan formula $C$ secara berurut adalah 5,$09 ; 5,11 ; 5,20$. Pemeriksaan $\mathrm{pH}$ ini dilakukan pada minggu ke-0.

Penelitian ini pengukuran viskositas menggunakan viskometer oswalt dimana hasil pengukuran dapat dilihat pada Tabel 2.

Pengukuran bobot jenis sediaan diperoleh bobot jenis formula $A$, formula $B$ dan formula $C$ berturut-turut adalah $1.104 \mathrm{~g} / \mathrm{mL}, 1.110 \mathrm{~g} / \mathrm{mL}$ dan $1.114 \mathrm{~g} / \mathrm{mL}$.

Tabel 2. Pengukuran viskositas setiap formula hair tonic

\begin{tabular}{c|c|c|c|c}
\hline \multirow{2}{*}{ Formula } & \multicolumn{4}{|c}{ Viskositas (Poise) } \\
\cline { 2 - 5 } & Minggu ke- 0 & $\begin{array}{c}\text { Minggu ke-8 } \\
\text { suhu tinggi }\end{array}$ & $\begin{array}{c}\text { Minggu ke-8 } \\
\text { suhu kamar }\end{array}$ & $\begin{array}{c}\text { Minggu ke-8 } \\
\text { suhu rendah }\end{array}$ \\
\hline Formula A & 0.0199 & 0.0208 & 0.0203 & 0.0199 \\
\hline Formula B & 0.0210 & 0.0188 & 0.0189 & 0.0183 \\
\hline Formula C & 0.0226 & 0.0195 & 0.0192 & 0.0192 \\
\hline
\end{tabular}

\section{Uji Stabilitas Sediaan}

Uji cycling test merupakan uji yang dilakukan dengan cara menyimpan sediaan hair tonic pada suhu $4{ }^{\circ} \mathrm{C}$ selama 24 jam kemudian dipindahkan pada suhu $40{ }^{\circ} \mathrm{C}$ selama 24 jam (satu siklus) yang dilakukan sebanyak 6 siklus.

Setelah dilakukan cycling test formula A memiliki kestabilan yang baik dari pada formula B dan C. Hal ini disebabkan terbentuknya endapan pada formula B dan C setelah dilakukan cycling test.

Sediaan yang disimpan pada suhu tinggi (suhu $40^{\circ} \mathrm{C} \pm 2{ }^{\circ} \mathrm{C}$ ) selama 8 minggu yang selanjutnya dilakukan evaluasi fisik setiap 2 minggu. Formula A memiliki kestabilan yang cukup baik pada penyimpanan suhu tinggi, dimana pada minggu ke-2 sampai minggu ke-8 warna dan homogenitas tetap. Sementara formula $B$ pada minggu ke-2 terjadi pengendapan meskipun warna sediaan tetap hijau sampai minggu ke-8. Namun, formula $\mathrm{C}$ terjadi pengendapan pada minggu ke-2 dan terjadi perubahan warna sediaan pada minggu ke-6.

Sediaan disimpan pada suhu kamar $\left(25{ }^{\circ} \mathrm{C} \pm 2{ }^{\circ} \mathrm{C}\right.$ ) selama 8 minggu dilakukan evaluasi fisik setiap 2 minggu. Formula $A$, formula $B$ dan formula $\mathrm{C}$ memiliki kestabilan warna yang baik pada penyimpanan suhu kamar, namun dari homogenitas formula A lebih baik karena homogen sampai minggu ke-8 sementara formula B terbentuk endapan pada minggu ke-4 dan formula $C$ terbentuk endapan pada minggu ke-2.

Sediaan disimpan pada suhu rendah $\left(4{ }^{\circ} \mathrm{C} \pm 2{ }^{\circ} \mathrm{C}\right)$ selama 8 minggu kemudian dilakukan evaluasi fisik setiap 2 minggu. Formula A tetap stabil pada penyimpanan suhu rendah dengan tidak mengalami perubahan warna hijau, sama halnya dengan formula $A$, formula $B$ dan formula $C$ 
juga tidak mengalami perubahan warna namun mengalami perubahan homogenitas yaitu terdapatnya endapan didasar botol pada minggu ke-2.

\section{Pengukuran Panjang Rambut dan Bobot Rambut}

\section{Pengukuran Panjang Rambut}

Tabel 3. Hasil pengukuran panjang rambut

\begin{tabular}{|c|c|c|}
\hline Kelompok perlakuan & Waktu & $\begin{array}{l}\text { Rata-rata Pertumbuhan Rambut } \\
\qquad(\mathrm{mm}) \pm \mathrm{SD}\end{array}$ \\
\hline \multirow{3}{*}{ Blanko } & Hari ke-8 & $3.245 \pm 0.127$ \\
\hline & Hari ke- 15 & $7.063 \pm 0.334$ \\
\hline & Hari ke- 22 & $11.365 \pm 0.071$ \\
\hline \multirow{3}{*}{ Kontrol Negatif } & Hari ke-8 & $3,260 \pm 0,176$ \\
\hline & Hari ke- 15 & $7.358 \pm 0.486$ \\
\hline & Hari ke- 22 & $12.345 \pm 0.320$ \\
\hline \multirow{3}{*}{ Formula A } & Hari ke-8 & $3.857 \pm 0.110$ \\
\hline & Hari ke- 15 & $9.175 \pm 0.049$ \\
\hline & Hari ke- 22 & $16.197 \pm 0.179$ \\
\hline \multirow{3}{*}{ Formula B } & Hari ke-8 & $3.867 \pm 0.088$ \\
\hline & Hari ke- 15 & $9.355 \pm 0.294$ \\
\hline & Hari ke- 22 & $14.602 \pm 0.190$ \\
\hline \multirow{3}{*}{ Formula C } & Hari ke-8 & $4.005 \pm 0.098$ \\
\hline & Hari ke- 15 & $8.192 \pm 0.344$ \\
\hline & Hari ke- 22 & $14.101 \pm 0.054$ \\
\hline \multirow{3}{*}{ Kontrol Positif } & Hari ke-8 & $4.130 \pm 0.186$ \\
\hline & Hari ke- 15 & $10.145 \pm 0.672$ \\
\hline & Hari ke- 22 & $18.583 \pm 0.264$ \\
\hline
\end{tabular}




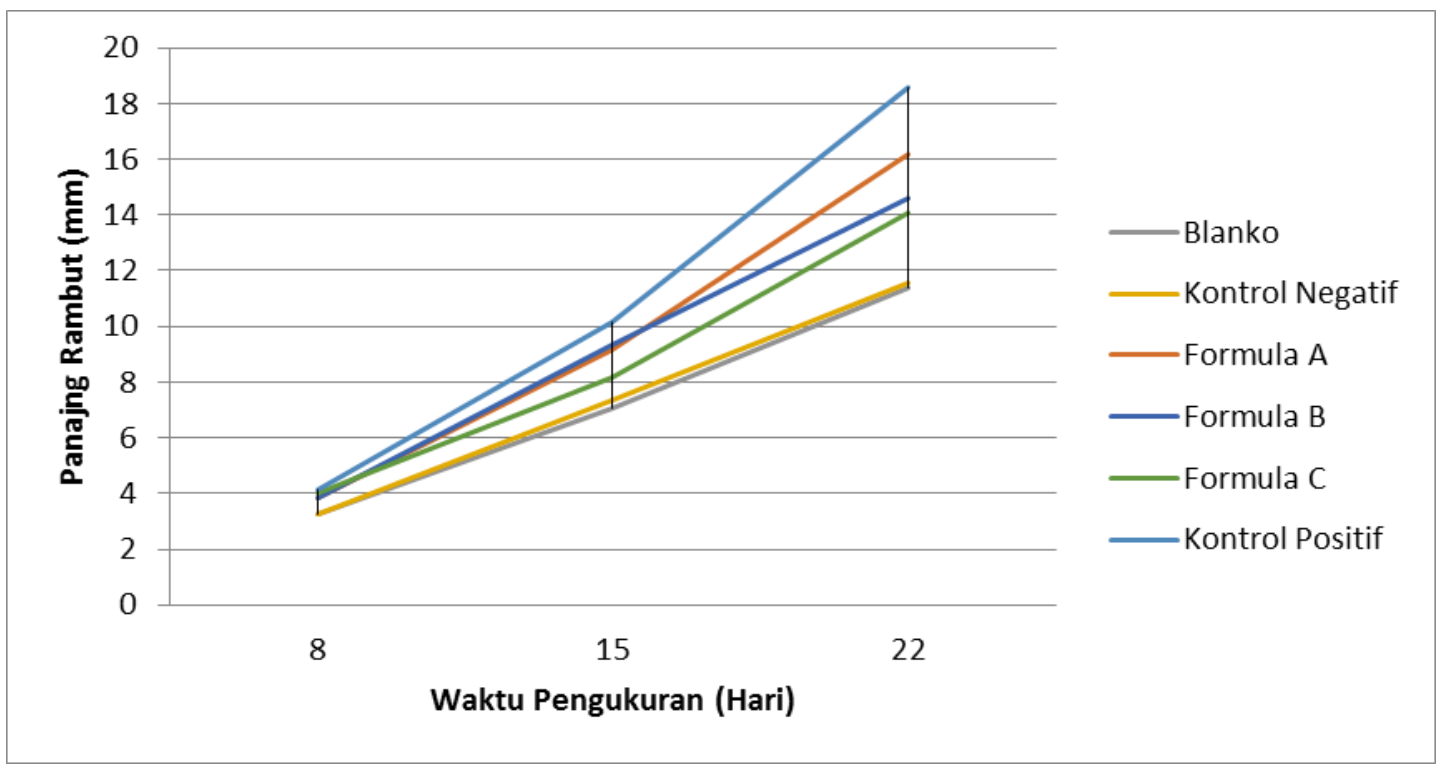

Gambar 4. Grafik pertumbuhan rambut kelinci

\section{Pengukuran Bobot Rambut Kelinci}

Tabel 4. Pengukuran Bobot Rambut Kelinci

\begin{tabular}{c|c}
\hline $\begin{array}{c}\text { Kelompok } \\
\text { Perlakuan }\end{array}$ & $\begin{array}{c}\text { Rata-rata Bobot } \\
\text { Rambut (mg) } \pm \text { SD }\end{array}$ \\
\hline Blanko & $386.625 \pm 0.921$ \\
\hline Kontrol Negatif & $387.325 \pm 0.822$ \\
\hline Formula A & $390.850 \pm 2.206$ \\
\hline Formula B & $386.900 \pm 1.321$ \\
\hline Formula C & $387.275 \pm 1.486$ \\
\hline Kontrol Positif & $392.100 \pm 2.296$ \\
\hline
\end{tabular}

\section{HASIL DAN PEMBAHASAN}

Tanaman yang digunakan pada penelitian ini adalah mangkokan. Bagian tanaman yang digunakan adalah daunnya. Daun mangkokan pada penelitian ini merupakan dari spesies Nothopanax scutellarium L. [5] maupun telah membuktikan bahwa daun mangkokan mampu meningkatkan aktivitas pertumbuhan rambut [6].

Sebelum digunakan dalam sediaan hair tonic, daun mangkokan dicuci bersih kemudian dibuat simplisia kering. Tujuan pembuatan simplisia kering agar simplisia dapat disimpan lebih lama karena tidak adanya kadar air pada simplisia yang merupakan media pertumbuhan jamur atau mikroba. Penggunaan kain hitam sebagai penutup simplisia saat penjemuran bertujuan untuk menghindari kontak langsung sinar matahari dengan simplisia karena sinar ultra violet dari matahari akan menimbulkan kerusakan pada kandungan kimia bahan yang dikeringkan [7]. Setelah simplisia kering dibuat selanjutnya dilakukan proses maserasi. Daun mangkokan segar yang digunakan adalah $4.2 \mathrm{~kg}$ yang kemudian dibuat simplisia dengan cara pengeringan menjadi $645 \mathrm{~g}$, selanjutnya dilakukan proses maserasi selama 4 kali pengulangan (4 hari) dengan etanol $70 \%$ yang menghasilkan maserat 8.7 liter. 
Pemilihan etanol sebagai pelarut pada maserasi didasarkan bahwa etanol dapat melarutkan basa, minyak atsiri, glikosida, kurkumin, kumarin, antrakinon, flavonoid, steroid, damar dan klorofil. Selanjutnya, maserat dipekatkan menggunakan rotary evaporator menghasilkan ekstrak kental sebanyak 242 g. Rotary evaporator digunakan tekanan 123 milibar, suhu $50{ }^{\circ} \mathrm{C}$ dan kecepatan putar 120 rpm. Penggunaan suhu rendah didasarkan karena senyawa metabolit sekunder mudah rusak pada suhu tinggi [8].

Pada pembuatan hair tonic ekstrak daun mangkokan digunakan basis yang terdiri dari etanol $96 \%$, propilen glikol, metil paraben, pewarna hijau, parfum jasmine dan aquadest. Etanol 96\% digunakan sebagai pelarut dari metil paraben dan sebagai antimikroba [9]. Propilen glikol digunakan sebagai kosolven, humektan dan plastisizer. Metil paraben sebagai pengawet digunakan karena adanya kandungan air dapat menjadi media pertumbuhan mikroba. Pada penelitian ini, dibuat formulasi dengan variasi pada konsentrasi ekstrak dengan basis yang sama, ini bertujuan untuk mencari formulasi terbaik untuk meningkatkan pertumbuhan rambut dan stabil pada saat penyimpanan.

Setelah sediaan hair tonic dibuat, maka dilakukan evaluasi awal meliputi organoleptis sediaan, $\mathrm{pH}$, viskositas dan bobot jenis sediaan. Evaluasi awal ini dimaksudkan sebagai pembanding ketika sediaan tersebut dilakukan uji stabilitas sehingga dapat dilihat perubahan organoleptis, $\mathrm{pH}$, viskositas dan bobot jenis sediaan sebelum dan sesudah uji stabilitas.

Hasil evaluasi awal formula A yaitu memiliki warna hijau, bau jasmine, homogen, $\mathrm{pH}$ 5.09, viskositas 0,01999
Poise, dan bobot jenis $1.104 \mathrm{~g} / \mathrm{ml}$. Formula B warna hijau, bau jasmine, homogen, $\mathrm{pH}$ 5.,11, viskositas 0.02105 Poise, dan bobot jenis 1.11 $\mathrm{g} / \mathrm{ml}$. Formula C warna hijau, bau jasmine, homogen, $\mathrm{pH} 5.2$, viskositas 0.02261 Poise, dan bobot jenis 1.114 $\mathrm{g} / \mathrm{ml}$.

Setelah dilakukan uji stabilitas yaitu cycling test, penyimpanan suhu tinggi, penyimpanan suhu kamar dan penyimpanan suhu rendah selama 8 minggu, hasil pengamatan organoleptis menunjukkan formula $A$ lebih stabil diberbagai suhu penyimpanan dari formula $B$ dan formula $C$ ini ditandai dengan warna, bau dan homogenitas sediaan yang tetap yaitu warna hijau, bau jasmine dan homogen saat evaluasi awal maupun evaluasi tiap 2 minggu dimasing-masing suhu penyimpanan. Sementara formula B dan formula C mengalami perubahan homogenitas yaitu terbentuknya endapan pada minggu ke-2 diberbagai suhu penyimpanan, meskipun formula $B$ masih homogen pada minggu ke-2 penyimpanan suhu kamar namun pada minggu ke-4 penyimpanan suhu kamar terjadi pengendapan juga pada formula B.

Selain mengalami perubahan homogenitas terjadi perubahan warna pada formula $\mathrm{C}$ yang terjadi pada minggu ke-6 dan ke-8 penyimpanan suhu tinggi yang semula hijau pada minggu ke-4 menjadi hijau coklat pada minggu ke- 6 dan coklat pada minggu ke-8.

Selanjutnya $\mathrm{pH}$ formula $\mathrm{A}$, formula $\mathrm{B}$ dan formula $C$ mengalami kenaikan ditiap suhu peyimpanan. Kenaikan $\mathrm{pH}$ ini dikarenakan menguapnya sebagian etanol sehingga sediaan semakin pekat, kandungan alkaloid pada ekstrak yang bersifat basa merupakan penyebab terjadinya 
kenaikan $\mathrm{pH}$. Kenaikan $\mathrm{pH}$ ini tidak begitu menjadi masalah karena masih dalam rentan $\mathrm{pH}$ aman kulit kepala yaitu 4,5-6,5.

Viskositas formula A, formula B dan formula $C$ setelah dilakukan uji stabilitas dapat dilihat pada Tabel 2 . Pada penyimpanan suhu tinggi dan suhu kamar pada formula A terjadi kenaikan viskositas ini disebabkan adanya penguapan etanol namun pada suhu rendah viskositas lebih stabil. Sementara viskositas formula B dan formula $C$ mengalami penurunan diberbagai suhu penyimpanan ini disebabkan banyaknya partikel ekstrak yang mengendap sehingga menurunkan kekentalan dari kedua sediaan ini.

Bobot jenis formula $A$, formula $B$ dan $C$ pada berbagai suhu penyimpanan diukur tiap 2 minggunya. Pada formula $A$, formula $B$ dan $C$ terjadi kenaikan bobot jenis yang bervariasi ini dikarenakan menguapnya etanol dan terbentuknya endapan sehingga meningkatkan bobot jenis dari sediaan.

Uji aktivitas pertumbuhan rambut dilihat berdasarkan panjang rambut dan bobot rambut. Pada pengukuran panjang rambut kelinci diambil 10 rambut terpanjang kemudian diukur menggunakan jangka sorong sementara pengukuran bobot rambut dilakukan pada hari ke-22 dengan mencukur semua rambut pada daerah uji kemudian ditimbang. Hasil uji aktivitas pertumbuhan rambut dapat dilihat pada Tabel 3 sementara hasil pengukuran bobot rambut kelinci dapat dilihat pada Tabel 4.

Pada penelitian ini dilakukan pengukuran panjang rambut tiap 7 hari selama 21 hari. Grafik pertumbuhan rambut dapat dilihat pada Gambar 3. Hasil uji Anova panjang rambut hari ke-8 dapat disimpulkan bahwa terdapat perbedaan yang nyata antar perlakuan, untuk mengetahui letak perbedaan nyata tersebut dilakukan uji BNT Kontrol negatif tidak berbeda nyata terhadap blanko namun berbeda nyata terhadap formula $A$, formula B dan formula C. Maka disimpulkan bahwa basis tidak memiliki pengaruh yang nyata terhadap pertumbuhan rambut ditinjau dari panjang rambut pada hari ke-8. Selanjutnya formula $A$, formula $B$ dan formula $C$ tidak nyata perbedaannya namun formula $A$ dan $B$ terhadap kontrol positif memiliki perbedaan yang nyata tidak seperti formula $C$ yang tidak berbeda nyata terhadap kontrol positif.

Rambut pada manusia rata-rata tumbuh sekitar 0.2-0.3 mm [10] sementara pada blanko yang tidak diberi sediaan hair tonic pertumbuhan rata-rata panjang rambut kelinci adalah $0.4 \mathrm{~mm}$ setiap harinya pada data panjang rambut hari ke-8. Selanjutnya dapat dilihat pada lampiran 20, formula $A, B$ dan $C$ berturut-turut memiliki persentase kemampuan meningkatkan pertumbuhan panjang rambut sebesar $15.878 \%, 16.137 \%$ dan $19.701 \%$ dari pertumbuhan panjang rambut tanpa perlakuan (blanko).

Pada hari ke 15, kontrol negatif tidak berbeda nyata terhadap blanko namun berbeda nyata terhadap formula $A$, formula $B$ dan formula $C$. Hasil ini bisa disimpulkan bahwa basis tidak memiliki pengaruh yang nyata terhadap pertumbuhan rambut ditinjau dari panjang rambut pada hari ke-15. Formula $A$ terhadap formula $B$ tidak memiliki perbedaan yang nyata namun berbeda nyata bila dibandingkan dengan formula $\mathrm{C}$ dimana formula $\mathrm{C}$ memiliki aktivitas pertumbuhan rambut yang lebih buruk 
dari pada formula $A$ dan formula $B$, ini disebabkan formula $C$ sudah tidak stabil sehingga bahan aktif mulai rusak dan tidak terdispersi sempurna dalam basis sediaan. Sementara kontrol positif masih berbeda nyata terhadap formula A dan formula B dengan memiliki aktivitas pertumbuhan rambut yang lebih baik dari pada formula $A$ dan $B$ pada hari ke-15.

Formula A, B dan C berturut-turut memiliki persentase kemampuan meningkatkan pertumbuhan panjang rambut sebesar 29,888\%; 32,436\% dan $15,979 \%$ dari pertumbuhan panjang rambut tanpa perlakuan (blanko).

Hari ke-22, kontrol negatif tidak berbeda nyata terhadap blanko namun berbeda nyata terhadap formula A, formula B dan formula $C$. Maka disimpulkan bahwa basis tidak memiliki pengaruh yang nyata terhadap pertumbuhan rambut ditinjau dari panjang rambut pada hari ke-22. Selanjutnya formula $A$ terhadap formula $B$ dan formula $C$ memiliki perbedaan nyata dengan formula $A$ memiliki aktivitas pertumbuhan rambut yang lebih baik dari formula $B$ dan $\mathrm{C}$, ini dikarenakan formula $\mathrm{A}$ tetap stabil dan zat aktif terdispersi sempurna sampai hari ke 22 sementara formula B dan C sudah tidak stabil dan zat aktif tidak terdispersi sempurna sehingga menurunkan kemampuan formula $B$ dan $C$ dalam meningkatkan aktivitas pertumbuhan panjang rambut.

Kontrol positif terhadap formula $A$ masih berbeda nyata seperti hari ke-8 dan ke-15 ini menunjukkan kontrol positif memiliki pertumbuhan rambut yang lebih baik dari formula $A$, formula B dan formula $C$ ditinjau dari panjang rambut. Selanjutnya dapat dilihat pada lampiran 20 formula A, B dan C berturut-turut memiliki persentase kemampuan meningkatkan pertumbuhan panjang rambut sebesar $42.520 \%, 28.486 \%$ dan $24.076 \%$ dari pertumbuhan panjang rambut tanpa perlakuan (blanko).

Blanko, kontrol negatif, formula B dan formula $\mathrm{C}$ tidak berbeda nyata antar perlakuan ditinjau dari bobot rambut namun berbeda nyata terhadap formula A dan kontrol positif. Formula A sendiri tidak berbeda nyata terhadap kontrol positif ini menunjukkan formula $A$ memiliki aktivitas pertumbuhan rambut yang hampir sama dengan kontrol positif ditinjau dari bobot rambut kelinci

Kemampuan ekstrak etanol daun mangkokan dalam meningkatkan aktivitas pertumbuhan rambut diduga karena adanya kandungan senyawa flavonoid, vitamin A, B1 dan C. Flavonoid dapat berfungsi sebagai antimikroba, antivirus dan antioksidan [8] sementara vitamin A, B1 dan C merupakan faktor nutrisi yang berperan dalam pertumbuhan rambut [3].

Senyawa yang diduga berefek sebagai peningkat aktivitas pertumbuhan rambut dapat disimpulkan bahwa hair tonic ekstrak etanol daun mangkokan merupakan golongan hair tonic yang bersifat zat conditioner rambut.

\section{KESIMPULAN DAN SARAN}

\section{Kesimpulan}

Berdasarkan penelitian uji aktivitas pertumbuhan rambut kelinci dari hair tonic yang mengandung ekstrak etanol daun mangkokan (Nothopanax scutellarium L.) dengan variasi konsentrasi 25\%, 35\% dan 45\%, dapat disimpulkan bahwa ekstrak 
etanol daun mangkokan (Nothopanax scutellarium L.) dapat dibuat sediaan hair tonic. Formula A memiliki aktivitas pertumbuhan rambut yang lebih baik dari formula $B$ dan formula $C$ namun kontrol positif masih lebih baik dari formula A ditinjau dari panjang rambut kelinci. Akan tetapi jika ditinjau dari bobot rambut, formula $A$ dan kontrol positif memiliki bobot rambut yang tidak berbeda nyata.

\section{Saran}

Perlu dilakukan penelitian lebih lanjut untuk mengetahui kandungan kimia ekstrak daun mangkokan yang berperan dalam aktivitas pertumbuhan rambut dan mekanismenya. Selain itu, perlu dilakukan formulasi hair tonic ekstrak daun mangkokan dengan basis yang berbeda sehingga zat aktif dapat terdispersi sempurna pada basis hair tonic dari ekstrak etanol daun mangkokan.

\section{DAFTAR PUSTAKA}

[1] Tranggono, R.I., Latifah, F. 2007. Buku Pegangan IImu Pengetahuan Kosmetik, Gramedia Pustaka Utama, Jakarta, 34-36.

[2] Mc Evoy, G.K. 1999. AHFS Drug Information, Bethesda, American Society of Health - System Pharmacist.

[3] Dalimartha, S., Soedibyo, M. 1999. Perawatan Rambut dengan Tumbuhan Obat dan Diet Suplemen, Swadaya, Jakarta, 110 dan 33.

[4] Setyoningsih. 2004. Efek Ekstrak Soxhletasi Daun Mangkokan (Nothopanax scutellarium Folium) Terhadap Uji
Pertumbuhan Rambut pada Kelinci Jantan. Skripsi, Fakultas Farmasi Universitas Setia Budi Surakarta.

[5] Sigit, H. 2005. Pengaruh Ekstrak Etanol Daun Mangkokan (Nothopanax scutellarium L.) Terhadap Pertumbuhan Rambut Kelinci Jantan dan Profil Kromatogram Lapis Tipisnya, Skripsi, Fakultas Farmasi Universitas Muhammadiyah, Surakarta.

[6] Tanaka, S. Saito, M., Tabata, M. 1980. Bioassay of Crude Drugs for Hair Growth Promoting Activity in Mice by a New Simple Method. Faculty of Pharmaceutical Sceinces Kyoto University, Japan.

[7] Pramono, S. 2006. Penanganan Pasca Panen dan Pengaruhnya Terhadap Efek Terapi Obat Alami. Prosiding Seminar Nasional Tumbuhan Obat Indonesia XXVIII, Bogor, 1-6.

[8] Robinson, T. 1995. Kandungan Organik Tumbuhan Tinggi.

Diterjemahkan oleh Kosasih Padmawinata, Institut Teknologi Bandung, Bandung.

[9] Rowe, R.C., Sheskey, P.J., Owen, S.C. 2009. Hand Book of Pharmaceutical Exipient, Sixth edition. American Pharmaceutical Association, London.

[10] Djuanda, A. 2005. IImu Penyakit Kulit dan Kelamin, Edisi IV, Fakultas Kedokteran Universitas Indonesia, Jakarta. 